\section{Carbon Dioxide and Ethylene: A Combined Influence on Potato Fry Color}

\author{
Barbara Daniels-Lake, ${ }^{1}$ Robert Prange, and John Walsh ${ }^{2}$ \\ Agriculture and Agri-Food Canada, Atlantic Food and Horticulture Research \\ Centre, 32 Main Street Kentville, Nova Scotia, B4N 1J5 Canada
}

Additional index words. Solanum tuberosum, potato storage, sucrose, glucose, fructose, sugars, reducing sugars, controlled atmosphere, modified atmosphere, $\mathrm{CO}_{2}, \mathrm{O}_{2}$

\begin{abstract}
For many years, the accepted wisdom among potato storage researchers and industry personnel linked the accumulation of $\mathrm{CO}_{2}$ in the storage atmosphere to darkening of potato fry color. Dark fry color is undesirable in the potato processing industry, as consumers prefer light-colored finished products. Previous research to elucidate the effect of $\mathrm{CO}_{2}$ has presented conflicting results. In three consecutive years of storage trials, the effects of elevated $\mathrm{CO}_{2}$ concentrations, reduced $\mathrm{O}_{2}$ concentrations and ethylene gas on the fry color and sugar content of 'Russet Burbank' potato (Solanum tuberosum L.) tubers were evaluated. The potatoes were stored in modified atmosphere chambers and selected atmosphere mixtures were supplied from compressed gas cylinders. Four 3-week trials were conducted in 2002 and two 9-week trials were conducted in each of 2003 and 2004. Fry color and tuber sugars were assessed at the start of each trial and after several weeks of exposure to the treatment atmospheres. Compared with untreated controls, increased $\mathrm{CO}_{2}$ alone or in combination with decreased $\mathrm{O}_{2}$ had little or no effect on fry color or tuber sugars. During the second and third years, only selected treatments were repeated, with or without the addition of $0.5 \mu \mathrm{L} \cdot \mathrm{L}^{-1}$ ethylene gas. Ethylene is known to affect potato fry color and reducing sugars. In three of four trials, tubers exposed to ethylene alone had darker fry color and higher reducing sugars compared with controls. Applied treatments had little or no effect on fry color and sugars in the fourth trial. Interestingly, in the same three of four trials, fry color of tubers exposed to both elevated $\mathrm{CO}_{2}$ and ethylene gas was not only darker than controls but also darker than tubers treated with ethylene alone. Similarly, reducing sugar concentrations were higher in tubers exposed to both ethylene and $\mathrm{CO}_{2}$ than with ethylene alone. No similar interaction between ethylene and oxygen concentration was observed. The results suggest a synergistic negative effect of trace ethylene and elevated $\mathrm{CO}_{2}$ on fry color, which may explain the apparently contradictory findings of some published research examining the effects of $\mathrm{CO}_{2}$ on potato fry color.
\end{abstract}

Fry color is an important quality characteristic in processed potato products such as French fries and potato chips. The light fry color preferred by consumers is produced when reducing sugar concentrations in the raw tubers are low (Burton et al., 1992; Mazza, 1983). Researchers and industry experts have long believed that the storage atmosphere can provoke increases in reducing sugars and darken fry color. Tuber respiration can deplete $\mathrm{O}_{2}$ and raise $\mathrm{CO}_{2}$ concentrations in the atmosphere surrounding the tuber, particularly when ventilation is restricted. For this reason most of the fry color research to date has focused on increases in $\mathrm{CO}_{2}$ and, to a lesser extent, decreases in $\mathrm{O}_{2}$.

Although early work by Denny and Thornton (1940) showed that $5 \mathrm{kPa} \mathrm{CO}_{2}$ prevents accumulation of reducing sugars during storage,

Received for publication 23 Mar. 2005. Accepted for publication 15 May 2005. Contribution 2300, Atlantic Food and Horticulture Research Centre, Agriculture and Agri-Food Canada. The authors wish to thank Kenneth McRae for expert guidance in statistics, and Kim Hiltz and Valerie Simmons for technical assistance. This work was supported in part by McCain Foods Ltd. and Cavendish Farms Inc. ${ }^{1}$ Corresponding author, email DanielsLakeB@agr. gc.ca.

${ }^{2}$ McCain Foods Ltd, 317 Main St, Florenceville, New Brunswick, E7L 3G6 Canada.
Blankson(1988) found that $\mathrm{CO}_{2}$ concentrations up to 2 to $3 \mathrm{kPa}$ have little effect on reducing sugar concentrations, whereas higher concentrations of $\mathrm{CO}_{2}$ (up to about $13 \mathrm{kPa}$ ) cause reducing sugars to rise substantially. Most research has shown that tubers stored with elevated $\mathrm{CO}_{2}$ concentrations $(0.5$ to $15 \mathrm{kPa})$ have higher reducing sugars and/or darker fry color than tubers stored at ambient concentrations of $\mathrm{CO}_{2}$ (Khanbari and Thompson, 1994, 1996; Mazza and Siemens,1990; Schouten, 1993a). Interestingly, recent extensive monitoring of several commercial storage buildings through a storage season found no correlation between the measured $\mathrm{CO}_{2}$ concentrations and the fry color changes observed (Walsh, unpublished data).

Depleted $\mathrm{O}_{2}$ concentrations accompany $\mathrm{CO}_{2}$ accumulation in potato stores. Very low $\mathrm{O}_{2}$ atmospheres ( 1 to $3 \mathrm{kPa}$ ) have been shown to both lower reducing sugar concentrations (Harkett, 1971; Sherman and Ewing, 1983) and to darken fry color (Khanbari and Thompson, 1994; Schouten, 1993b). Schwobe and Parkin (1990) found the effect varied among cultivars. However, the influence of more moderate $\mathrm{O}_{2}$ depletion on potato fry color has not been reported.

Ventilation with external air to control temperature and humidity in the store is generally assumed to restore $\mathrm{CO}_{2}$ and $\mathrm{O}_{2}$ to ambient concentrations (Burton et al., 1992; Rastovski, 1987a; Smith, 1967). However, peak $\mathrm{CO}_{2}$ concentrations measured in ventilated potato stores range from 0.6 to $14 \mathrm{kPa}$ (Mazza and Siemens, 1990; Schaper etal., 1993). Rastovski (1987b) and Schaper et al. (1993) recommend that the $\mathrm{CO}_{2}$ concentration within potato stores should be maintained below $1 \mathrm{kPa}$.

Based on previous work with potatoes and ethylene gas (Daniels-Lake etal., 2005; Prange et al., 1998), it was hypothesized that ethylene may be involved in the fry color darkening previously reported to be associated solely with elevated $\mathrm{CO}_{2}$. Exposure to low concentrations of ethylene $\left(0.4\right.$ to $\left.40 \mu \mathrm{L} \cdot \mathrm{L}^{-1}\right)$ is known to increase reducing sugar concentrations and darken potato fry color (Daniels-Lake et al., 2005; Prange et al., 1998). The response varies among cultivars (Haard, 1971; Prange and Daniels-Lake, unpublished data) and darkening is concentration-dependent below about $4 \mu \mathrm{L} \cdot \mathrm{L}^{-1}$ (Daniels-Lake et al., 2005). Ethylene is a metabolic product of potato tubers (Poapst et al., 1968; Suttle 2003) and the rate of production increases in response to stress (Creech etal., 1973; Korableva and Ladyzhenskaya, 1995; McGlasson, 1969; Poapst et al., 1968). Numerous potato storage pathogens also produce ethylene (summarized in Arshad and Frankenberger, 2002b). The ethylene gas can accumulate to metabolically-significant concentrations around the tuber, particularly when ventilation is restricted. However an interaction of ethylene with either elevated $\mathrm{CO}_{2}$ or decreased $\mathrm{O}_{2}$ atmospheres, and its potential to influence potato fry color or reducing sugars, have not been well examined. Duncan and Kraish(1999) speculated on a possible interaction, but no evidence was provided.

Trials were initiated in January 2002 at the postharvest physiology facilities at Agriculture and Agri-Food Canada's Atlantic Food and Horticulture Research Centre (AFHRC) in Kentville, Nova Scotia, Canada to elucidate the effects of $\mathrm{CO}_{2}$ and $\mathrm{O}_{2}$ on potato fry color and tuber sugars. A low concentration of ethylene gas was included in the 2003 and 2004 trials to identify possible interactions among ethylene, $\mathrm{O}_{2}$ and $\mathrm{CO}_{2}$.

\section{Materials and Methods}

Experimental material. Trials were conducted during 3 consecutive years, i.e., January to June of 2002, 2003, and 2004, using commercially grown 'Russet Burbank' potatoes harvested in mid-October of each preceding growing season. Within each year, potatoes were sourced from eight (2002) or four (2003, 2004) different potato growers located in New Brunswick, Canada. After arrival at AFHRC, the potatoes were held for 4 weeks at $13{ }^{\circ} \mathrm{C}$ to permit suberization and wound healing, gradually cooled to $9{ }^{\circ} \mathrm{C}$ over 4 weeks, and dipped in early December in a $1 \%$ a.i. water emulsion of chlorpropham (Sprout-Nip EC, isopropyl $\mathrm{n}$-(3-chlorophenyl) carbamate, $320 \mathrm{~g} \cdot \mathrm{L}^{-1}$ a.i., Stanchem Inc., Etobicoke, Ontario, Canada) to control sprouting. Samples of 10 tubers (about $2 \mathrm{~kg}$ ) were placed in mesh bags and stored at $9{ }^{\circ} \mathrm{C}$ in $0.1-\mathrm{m}^{3}$ ventilated aluminum chambers 
(constructed locally) during the trials. Each atmosphere was delivered to two chambers. Samples from half of the potato sources were assigned to each of a pair of chambers according to the statistical design. One (2002) or three (2003 and 2004) samples from each of the assigned sources were placed in each chamber at the start of each trial. Relative humidity within the chambers was maintained at $95 \%$ to $99 \%$ throughout the trials.

Modified atmosphere treatments. In 2002, four 3-week trial repetitions were conducted consecutively, beginning in February, March, April, and June. In each trial, modified atmosphere treatments of $21,20.5$, or $19 \mathrm{kPa} \mathrm{O}$ with $0,0.5$, or $2 \mathrm{kPaCO}_{2}$ in a factorial design were maintained in the chambers for 3 weeks. In addition, unventilated (sealed) chambers simulated conditions in a poorly-ventilated potato storage building.

In 2003 and 2004, two 9-week trial repetitions were carried out in each year, i.e., January to March (January trial) and April to June (April trial). Modified atmospheres of 21 or $19 \mathrm{kPa}$ $\mathrm{O}$, with 0 or $2 \mathrm{kPaCO}$, with or without the addition of $0.5 \mu \mathrm{L} \cdot \mathrm{L}^{-1}$ ethylene gas, were applied in a factorial design. In addition, sealed chambers, with or without $0.5 \mu \mathrm{L} \cdot \mathrm{L}^{-1}$ ethylene, were also employed. In 2004, the $21 \mathrm{kPa} \mathrm{O}_{2}$ and the sealed without ethylene treatments were not included, due to space limitations.

In all trials during all years, chambers flushed with compressed air (medical-quality air, Praxair Ltd, Dartmouth, Nova Scotia, Canada) held control samples in all trials. Chambers flushed with medical air plus 0.5 $\mu \mathrm{L} \cdot \mathrm{L}^{-1}$ ethylene held ethylene check samples (2003 and 2004 only).

The desired atmospheres were achieved by flushing the chambers for 30 min every 6 $\mathrm{h}$ with selected gas mixtures supplied from compressed gas cylinders (Praxair Ltd, Dartmouth, Nova Scotia, Canada), delivered at 1.5 to $1.8 \mathrm{~L} \cdot \mathrm{min}^{-1}$ through $3.2 \mathrm{~mm}$ OD nylon tubing (Cole Parmer-Labcor Technical Sales Inc, Anjou, Quebec, Canada). The ventilation schedule was managed by a multichannel timer (ChronTrol, Labcor Sales, Anjou, Quebec, Canada). In the chambers designated $0 \mathrm{kPa}$ $\mathrm{CO}_{2}$, small paper bags containing hydrated lime (Graymont (QC) Inc, Marbleton, Quebec, Canada) scrubbed the ambient and respired $\mathrm{CO}_{2}$. Atmospheres were checked several times per week using an $\mathrm{O}_{2}, \mathrm{CO}_{2}$ gas analyser ( ICA40, International Controlled Atmosphere, Tonbridge, Kent, U.K., in the 2002, 2003, and January 2004 trials; Checkpoint, PBI Dansensor America, Glen Rock, N.J., in the April 2004 trial). Chamber atmosphere compositions were corrected when necessary by additional flushing with the compressed gases. At 3-week intervals all chambers were opened briefly to remove samples for fry color and sugar evaluations, which returned the chamber atmospheres to ambient concentrations. The modified atmospheres were subsequently reestablished within several hours after the chambers were reclosed.

Ethylene was distributed to the chambers either from a separate cylinder through a gas distribution board built on-site (2003 January trial and throughout 2004) or included in the cylinder premix (2003 April trial). The ethylene concentration in the chambers was $0.5 \pm 0.15$ $\mu \mathrm{L} \cdot \mathrm{L}^{-1}$. Ethylene was monitored automatically using a Shimadzu 8A gas chromatograph(Mandel Scientific, Guelph, Ontario, Canada) with a PI-52-02A photo-ionization detector (HNU Systems, Newton, Mass.), a 2-m stainlesssteel column hand-packed with $60 / 80$ mesh alumina and nitrogen carrier gas, at $105{ }^{\circ} \mathrm{C}$ injector, $100{ }^{\circ} \mathrm{C}$ column and $120{ }^{\circ} \mathrm{C}$ detector temperatures. Atmosphere samples were drawn sequentially from the chambers by a sample-and-return system built on-site using a computer-controlled sequencer (Sciemetric Instruments, Ottawa, Ontario, Canada), and delivered to a six-port rotary valve (Valco Instruments, Houston, Texas) on the GC injection port. Each chamber was sampled at 2-h intervals, $24 \mathrm{~h} \cdot \mathrm{d}^{-1}$ throughout the trials. The ethylene concentration in the chambers was corrected when necessary by manual adjustment of needle valves (Nupro, Mandel Scientific, Guelph, Ontario, Canada) on the gas distribution board, except in the April 2003 trial when corrections were made by additional flushing with the premixed gases.

Evaluations. Potato fry color and sugars were evaluated upon arrival at AFHRC in October of each year, at the start of each trial and after 3 (all years), 6, and 9 (2003 and 2004) weeks of treatment. One sample from each source $\mathrm{x}$ treatment combination was assessed at each evaluation date. To evaluate fry color, a $5-\mathrm{cm}$ disk was cut from the middle of an 8 $\mathrm{mm}$-thick central longitudinal slice from each of the tubers in a sample. The disks were fried at $190{ }^{\circ} \mathrm{C}$ in canola oil (Maple Leaf Foods, Moncton, New Brunswick, Canada) for 2.5 min, drained for $1 \mathrm{~min}$ and the excess oil absorbed on paper toweling. After cooling to room temperature, the color of each disk was measured using an Agtron reflectance colorimeter (model M35-D; Agtron Inc, Sparks, $\mathrm{Nev}$.) on the green setting and calibrated using Agtron standard reflectance discs \#00 (black) as zero and \#56 (very pale grey) as $100 \%$ reflectance. Tuber sugars (sucrose, glucose and fructose concentrations) of freeze-dried subsamples of tuber tissue were determined by an enzymatic assay adapted from the method of Viola and Davies (1992). Total reducing sugar content was calculated as glucose plus fructose.

Statistical design. The customized experimental design followed a replicated split-split plot design for the chambers; the sources formed the first split and the samples (preassigned to evaluation dates) formed the second split. A generalized ANOVA analysis using Genstat V statistical software (Genstat Committee, 1993) partitioned the sources of variation according to the replication and randomization of the experimental effect. When significant differences $(p \leq 0.05)$ were identified, pairs of data were compared using the least significant difference (LSD). ANOVA analysis was also applied to the 2002 and 2003 data to contrast the factorial combinations of $\mathrm{O}_{2}$ and $\mathrm{CO}_{2}$ with the control, ethylene and sealed treatments.

\section{Results and Discussion}

The initial fry color and sugar content of the tubers at receipt in October and prior to the start of each trial varied among years, among sources within each year and among trial start dates within each year, reflecting differences attributable to production locations, growing seasons, maturity at harvest and the length of time in storage. For example, the mean initial fry colors upon arrival at AFHRC were 74.4, 65.2, and 80.8 Agtron percent reflectance units (ARU) in October 2001, 2002, and 2003, respectively. Mean initial reducing sugar concentrations were $9.0,7.4$, and $5.0 \mathrm{mg} \cdot \mathrm{g}^{-1}$ dry weight in October 2001, 2002, and 2003, respectively. These were within the normal range of variability of 'Russet Burbank' grown in eastern Canada (Daniels-Lake and Prange, unpublished). Inclusion of multiple sources of potatoes and repetition of the trials within and among years ensured a robust evaluation of the effects of the applied treatments despite the variability. While the treatment responses attributable to year, trial start date or source varied somewhat in magnitude, the nature of responses to the treatments remained consistent among years and among trials within years. In 2002 and 2003 there were no differences between trials within each year. Therefore the data is presented as treatment means of all trials within a year, except for 2004 in which the January and April trial data are presented separately.

Within each trial, there was no statistical interaction between evaluation dates and treatments in either fry color or sugar concentration. The main effects of treatment and evaluation date were significant in most trials; treatment differences are discussed at length below. Fry color and sugar concentrations in potato tubers change gradually during storage, reflecting the natural progression of the tubers through maturation, dormancy, dormancy break and sprouting (Burton et al., 1992; Storey and Davies, 1992). Although potato cultivars are genetically uniform, sugars and fry color at harvest, and the rate of progression through these stages, may vary slightly from year to year due to the effects of location, weather and cultural conditions during growth of the crop (Burton et al., 1992). External factors such as storage temperature can also affect fry color and sugars, but these were carefully controlled during the trials. Although statistically significant differences between evaluation dates were identified in this work, the differences were small in comparison to treatment differences and were within the natural variability of the material. More importantly, there were no significant interactions between treatment and time (i.e., evaluation dates) in either fry color or sugars. Therefore, in a effort to be succinct, differences attributable to time will not be discussed further.

In the sealed chambers, $\mathrm{O}_{2}$ and $\mathrm{CO}_{2}$ concentrations were slowly modified by the respiratory activity of the tubers. The extreme gas concentrations reached in these chambers, just before opening at 3-week intervals to remove samples for evaluation, were about 16 
$\mathrm{kPa} \mathrm{O}_{2}$ and $4 \mathrm{kPa} \mathrm{CO}$. Therefore the sealed chambers functioned as elevated $\mathrm{CO}_{2} /$ depleted $\mathrm{O}_{2}$ treatments.

In all trials conducted in 2002 and 2003, there were no differences in fry color attributable to the main effects of either reduced
$\mathrm{O}_{2}$ or elevated $\mathrm{CO}_{2}$ concentrations, or their interaction (Table 1). Tuber sugar concentrations (sucrose, glucose, fructose and total reducing sugars) were similarly unaffected (data not presented). In the January 2004 trial only, the mean fry color of tubers exposed to

Table 1. Fry color of potatoes stored in atmospheres having modified oxygen and carbon dioxide concentrations. Values for 2002 are means of the 3 -week evaluations in four consecutive 3 -week trials $\times 8$ potato sources per trial. Values for 2003 are means of 3-, 6- and 9-week evaluations in two consecutive 9-week trials $\times 4$ sources per trial. Fry color was measured with an Agtron reflectance colorimeter where $0=$ black and $100=$ very pale grey (almost white).

\begin{tabular}{|c|c|c|c|c|}
\hline \multirow[b]{2}{*}{ Treatment } & \multicolumn{2}{|c|}{ Gas concn } & \multicolumn{2}{|c|}{$\begin{array}{c}\text { Fry color } \\
\text { Agtron percent reflectance units } \\
(\% \text { reflectance })\end{array}$} \\
\hline & $\mathrm{O}_{2}(\mathrm{kPa})$ & $\overline{\mathrm{CO}_{2}(\mathrm{kPa})}$ & 2002 & 2003 \\
\hline Air & Ambient & Ambient & 70.9 & 62.8 \\
\hline Sealed & Declining $^{z}$ & Rising $^{y}$ & 69.4 & 60.9 \\
\hline \multirow[t]{9}{*}{ Modified atmospheres } & 21 & 0 & 70.7 & 62.8 \\
\hline & & 0.5 & 69.3 & $---^{x}$ \\
\hline & & 2 & 69.3 & 62.7 \\
\hline & 20.5 & 0 & 71.4 & --- \\
\hline & & 0.5 & 70.9 & --- \\
\hline & & 2 & 69.3 & --- \\
\hline & 19 & 0 & 71.6 & 61.2 \\
\hline & & 0.5 & 70.5 & --- \\
\hline & & 2 & 68.8 & 62.0 \\
\hline $\operatorname{SE}(p>0.05)^{\mathrm{w}}$ & & & $1.749(\mathrm{n}=32)$ & $1.323(\mathrm{n}=24)$ \\
\hline
\end{tabular}

${ }^{\mathrm{z}} \mathrm{O}_{2}$ concentration declined as tubers respired, to a minimum of about $16 \mathrm{kPa}$.

${ }^{\mathrm{y}} \mathrm{CO}_{2}$ accumulated from tuber respiration, to a maximum of about $4 \mathrm{kPa}$.

Treatment combination which was not applied in that year.

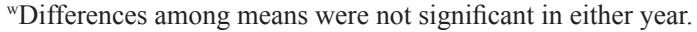

Table 2. Fry color of potatoes stored in atmospheres having modified oxygen and carbon dioxide concentrations, with or without $0.5 \mu \mathrm{L} \cdot \mathrm{L}^{-1}$ ethylene. Fry color measurement as in Table 1. Values for 2003 calculated as in Table 1. Data for the January and April 2004 trials are presented separately; values are means of the 3-, 6-, and 9-week evaluations $\times 4$ sources per trial.

\begin{tabular}{|c|c|c|c|c|}
\hline & & \multicolumn{3}{|c|}{$\begin{array}{c}\text { Fry color } \\
\text { Agtron percent reflectance units } \\
(\% \text { reflectance })\end{array}$} \\
\hline \multicolumn{2}{|c|}{ Treatment } & 2003 & 2004 & \\
\hline Atmosphere & Ethylene & January and April & January & April \\
\hline Air & - & $62.8 \mathrm{a}^{\mathrm{z}}$ & $76.2 \mathrm{a}$ & $82.9 \mathrm{a}$ \\
\hline $0 \mathrm{kPa} \mathrm{CO}_{2}^{\mathrm{y}}$ & - & $62.0 \mathrm{a}$ & $74.8 \mathrm{ab}$ & $85.0 \mathrm{a}$ \\
\hline $2 \mathrm{kPa} \mathrm{CO}_{2}{ }^{\mathrm{y}}$ & - & $62.4 \mathrm{a}$ & $71.5 \mathrm{c}$ & $82.7 \mathrm{a}$ \\
\hline Sealed & - & $60.9 \mathrm{a}$ & $--{ }^{x}$ & --- \\
\hline Air & + & $55.2 \mathrm{~b}$ & $73.4 \mathrm{abc}$ & $67.0 \mathrm{~b}$ \\
\hline $0 \mathrm{kPa} \mathrm{CO}{ }_{2}^{\mathrm{y}}$ & + & $56.0 \mathrm{~b}$ & 72.9 bc & $66.5 \mathrm{bc}$ \\
\hline $2 \mathrm{kPa} \mathrm{CO}^{\mathrm{y}}$ & + & $48.5 \mathrm{c}$ & $72.4 \mathrm{bc}$ & $61.6 \mathrm{bc}$ \\
\hline Sealed & + & $46.8 \mathrm{c}$ & $71.3 \mathrm{c}$ & $57.9 \mathrm{c}$ \\
\hline $\operatorname{SE}(p<0.05)$ & & $1.045(\mathrm{n}=24)$ & $0.860(n=12)$ & $2.598(\mathrm{n}=12)$ \\
\hline
\end{tabular}

${ }^{\mathrm{z}}$ Means within a column which are followed by the same letter are not significantly different $(\mathrm{p}<0.05)$.

y Mean of results from 19 and $21 \mathrm{kPa}$ oxygen atmospheres in 2003; $19 \mathrm{kPa}$ oxygen in 2004.

${ }^{\mathrm{x}}$ Treatment combination, which was not applied in that year.

Table 3. Total reducing sugars (glucose + fructose) in potato tubers stored in atmospheres having modified oxygen and carbon dioxide concentrations, with or without $0.5 \mu \mathrm{L} \cdot \mathrm{L}^{-1}$ ethylene. Values calculated as in Table 2.

\begin{tabular}{|c|c|c|c|c|}
\hline & & \multicolumn{3}{|c|}{$\begin{array}{l}\text { Total reducing sugars } \\
\left(\mathrm{mg} \cdot \mathrm{g}^{-1} \text { dry wt }\right)\end{array}$} \\
\hline \multicolumn{2}{|c|}{ Treatment } & 2003 & 2004 & \\
\hline Atmosphere & Ethylene & January and April & January & April \\
\hline Air & - & $9.0 \mathrm{a}^{\mathrm{z}}$ & $5.7 \mathrm{a}$ & $4.0 \mathrm{a}$ \\
\hline $0 \mathrm{kPa} \mathrm{CO}_{2}^{\mathrm{y}}$ & - & $9.1 \mathrm{a}$ & $5.7 \mathrm{a}$ & $3.8 \mathrm{a}$ \\
\hline $2 \mathrm{kPa} \mathrm{CO}_{2}^{\mathrm{y}}$ & - & $8.9 \mathrm{a}$ & $7.3 \mathrm{~b}$ & $3.7 \mathrm{a}$ \\
\hline Sealed & - & $9.6 \mathrm{a}$ & $---x$ & --- \\
\hline Air & + & $13.0 \mathrm{~b}$ & $7.2 \mathrm{~b}$ & $7.8 \mathrm{~b}$ \\
\hline $0 \mathrm{kPaCO}_{2}{ }^{\mathrm{y}}$ & + & $12.1 \mathrm{~b}$ & $7.9 \mathrm{~b}$ & $8.6 \mathrm{~b}$ \\
\hline $2 \mathrm{kPa} \mathrm{CO}_{2}^{\mathrm{y}}$ & + & $15.4 \mathrm{c}$ & $7.6 \mathrm{~b}$ & $9.3 \mathrm{bc}$ \\
\hline Sealed & + & $17.0 \mathrm{c}$ & $7.9 \mathrm{~b}$ & $10.6 \mathrm{c}$ \\
\hline $\operatorname{SE}(p<0.05)$ & & $0.437(n=24)$ & $0.320(\mathrm{n}=12)$ & $0.670(\mathrm{n}=12)$ \\
\hline
\end{tabular}

${ }^{\mathrm{z}}$ Means within a column which are followed by the same letter are not significantly different $(p<0.05)$.

${ }^{\mathrm{y}}$ Mean of 19 and $21 \mathrm{kPa}$ oxygen atmospheres in 2003; $19 \mathrm{kPa}$ oxygen in 2004.

xTreatment combination which was not applied in that year.

the $19 \mathrm{kPa} \mathrm{O}$ plus $2 \mathrm{kPa} \mathrm{CO}$ atmosphere was about 5 ARU lower (i.e., darker color) and reducing sugar concentration was about 1.5 $\mathrm{mg} \cdot \mathrm{g}^{-1}$ dry weight higher than in the control tubers (Tables 2 and 3). In the April 2004 trial, there was no difference in fry color or reducing sugars attributable to either the main effects or the interaction of reduced $\mathrm{O}_{2}$ or elevated $\mathrm{CO}_{2}$ (without ethylene).

In three of the four trials conducted during 2003 and 2004, fry color was darker in tubers which were exposed to ethylene alone in comparison with control samples (Table 2 ). The change in fry color attributable to ethylene alone was -8 to-17 ARU (i.e., darker color) compared with controls in the 2003 and April 2004 trials. In the January 2004 trial, fry color of tubers from the air plus ethylene check did not differ significantly from the air control. It should be noted, however, that fry color values varied $<5$ ARU from highest to lowest in the January 2004 trial. This range was much smaller than observed in the 2003 and April 2004 trials, i.e., a range of 16 and 27 ARU, respectively (Table 2). Such a lack of response to ethylene is somewhat unusual, but is not entirely unknown. During more than 14 years of ethylene research conducted on 'Russet Burbank' at AFHRC, a similar lack of fry color response in mid-winter following ethylene exposure has been observed in some years (Daniels-Lake and Prange, unpublished data). It is attributable to the growing season and field location, specifically the maturity of the tubers which influences sugar content at harvest and during subsequent storage (Burton et al., 1992). In some cultivars, fry color is actually improved by exposure to ethylene during cold storage (Haard, 1971).

Interestingly, in the 2003 and April 2004 trials the tubers which were exposed to both ethylene and elevated $\mathrm{CO}_{2}$ had fry color 5 to 8 ARU lower (i.e., fry color was darker) than with ethylene alone, or 14 to 25 ARU lower than the control tubers stored in air without ethylene (Table 2). For example, in the April 2004 trial the fry color of tubers from the sealed plus ethylene treatment was darker than tubers exposed to the air plus ethylene check, $\mathrm{CO}_{2}$ or the air control $(58,67,83$ and 83 ARU, respectively). This suggests an interaction between the two gases which affected potato fry color. Such an interaction has not been previously described.

The combined effect of ethylene and $\mathrm{CO}_{2}$ was particularly evident when the values at each evaluation were considered. Representative fry color data from the April 2004 trial are provided to illustrate this (Fig. 1). Separation of the data into three groups is apparent, i.e.: 1) those treatments which did not receive ethylene, with or without elevated $\mathrm{CO}_{2}$, which had the lightest fry color; 2) the ethylene-only treatments, which had darker fry color than the first group; and 3) those treatments which received both elevated $\mathrm{CO}_{2}$ and ethylene gas (including the sealed plus ethylene treatment), which had the darkest fry color within the trial. Although elevated $\mathrm{CO}_{2}$ alone did not darken fry color, the darkening of fry color in response to ethylene was more severe when $\mathrm{CO}_{2}$ was 

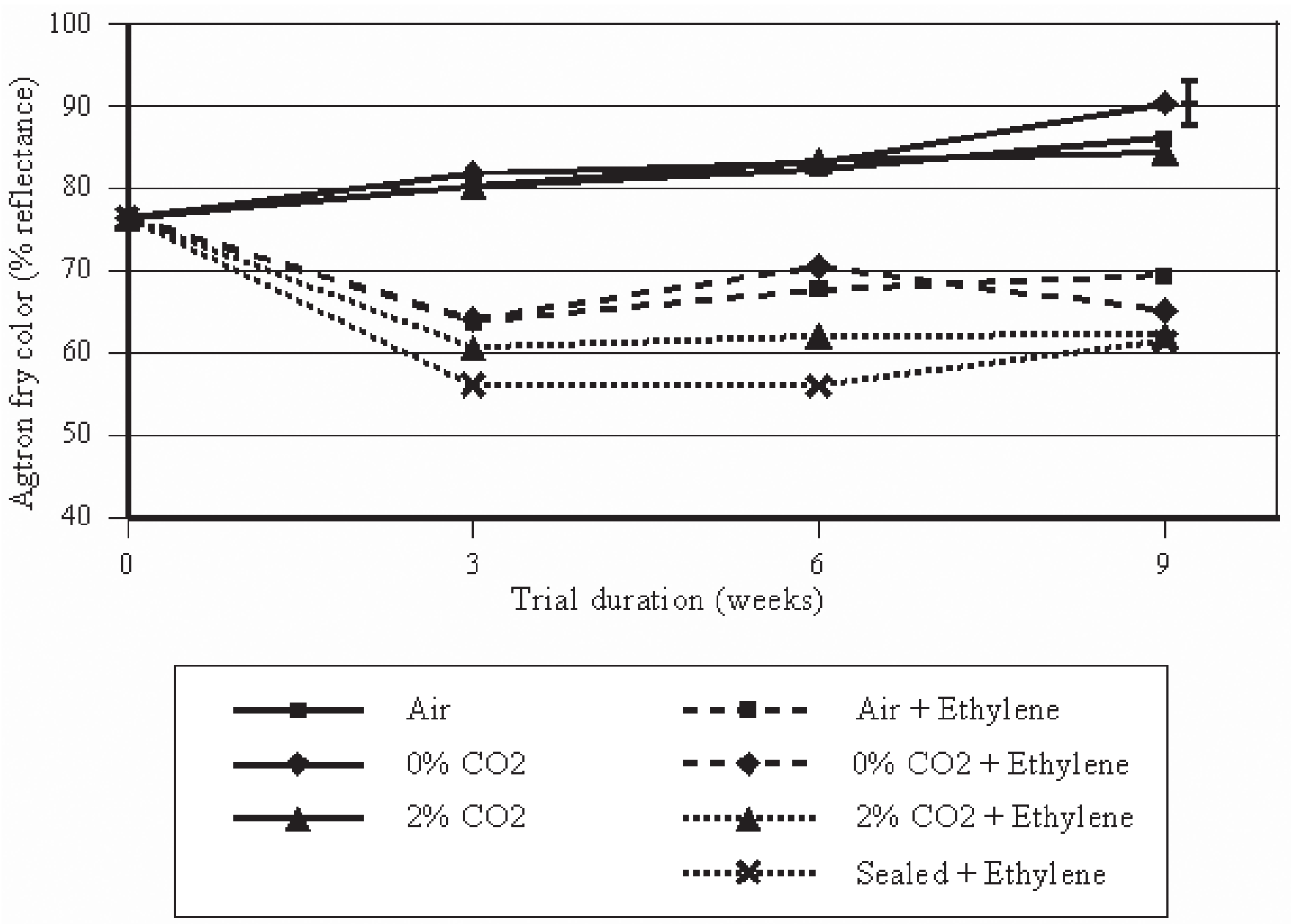

Fig. 1. Fry color of potatoes stored from April to June 2004 in atmospheres having modified oxygen and carbon dioxide concentrations, with or without $0.5 \mu \mathrm{L}$ ethylene. Significant effects: treatment $(\mathrm{SE}=2.598, p=0.001)$, time $(\mathrm{SE}=0.882, p=0.003)$; treatment $\times$ time interaction nonsignificant.

also present. Separation of the treatments into these groups was apparent at the first evaluation date (3 weeks after the start of the trial) and remained consistent to the end of the trial(Fig. 1). The main effects of treatment and time were significant $(p=0.001$ and 0.003 , respectively). Treatment effects were as previously discussed. Mean fry colour changed slightly during the trial, i.e., 70, 72, and $74 \mathrm{ARU}$ at 3, 6, and 9 weeks, respectively. There was no statistical interaction between these factors, which indicated that the treatment effects were not influenced by the duration of storage, within the time-frame studied.

Tuber sugars (sucrose, glucose, and fructose) in the 2003 and 2004 trials were influenced by ethylene and $\mathrm{CO}_{2}$ in a manner similar to the effect on fry color, i.e., sugar values were increased in treatments where fry color darkened and vice versa (Table 3 ). Since fry color depends primarily on the reducing sugar content of the tubers and sucrose has little direct effect on color at the frying temperature used (Burton et al., 1992), further discussion of sugars will focus on total reducing sugars, i.e., glucose plus fructose.

The combined effect of ethylene and $\mathrm{CO}_{2}$ was also evident in reducing sugar content in the 2003 and April 2004 trials (Table 3). Exposure to $\mathrm{CO}_{2}$ alone had little or no effect upon reducing sugar content, while exposure to ethylene alone led to increased reducing sugars. Reducing sugar concentrations were still higher in tubers exposed to both ethylene and $\mathrm{CO}_{2}$, although in the April 2004 trial only tubers from the sealed plus ethylene treatment had significantly higher reducing sugars than tubers from the ethylene without $\mathrm{CO}_{2}$ treatment. In the January 2004 trial, reducing sugar concentrations were higher in tubers exposed to $\mathrm{CO}_{2}$, ethylene or both, compared with the controls (Table 3 ). As observed in regard to fry color, the range of reducing sugar concentrations was smaller in the January 2004 trial than in the 2003 or April 2004 trials (2.2, 8.1 and 6.9 $\mathrm{mg} \cdot \mathrm{g}^{-1}$ dry weight, respectively). The minimal response to ethylene is likely attributable to the differences in maturity of the tubers, as discussed previously.

Potato tubers naturally produce ethylene at a low rate, i.e., 0.0008 to $0.015 \mu \mathrm{L} \cdot \mathrm{kg}^{-1} \cdot \mathrm{h}^{-1}$ from intact tubers (Creech etal., 1973; Korableva and Ladyzhenskaya, 1995; McGlasson, 1969). The rate of production increases 2 - to 25 -fold in response to chilling, warming, sprouting, injury, infection by some pathogens and exposure to external ethylene (Arshad and Frankenberger, 2002a; Creech et al., 1973; Korableva and Ladyzhenskaya, 1995; McGlasson, 1969; Poapst et al., 1968). Poapst et al. (1968) found the internal ethylene concentration of potato tubers to be $0.7 \mu \mathrm{g} \cdot \mathrm{kg}^{-1} \mathrm{FW}$. Many pathogens which infect potato tubers are known to produce ethylene (summarized in Arshad and Frankenberger, 2002b). Furthermore, commercial application of the chlorpropham sprout inhibitor by thermal fogging produces ethylene gas which often enters the storage atmosphere with the chlorpropham fog (Duncan, 1999; Duncan and Kraish, 1999). Stored potatoes may therefore be unintentionally exposed to ethylene gas. In fact, significant concentrations of ethylene (up to $40 \mu \mathrm{L} \cdot \mathrm{L}^{-1}$ ) in commercial potato stores have been recorded (A. Briddon, personal communication; Duncan, 1999). Low concentrations of ethylene $\left(>0.4 \mu \mathrm{L} \cdot \mathrm{L}^{-1}\right)$ increase reducing sugar concentrations and darken fry color in a concentration-dependent manner (Daniels-Lake et al., 2005; Prange et al, 1998) which varies among cultivars (Prange and Daniels-Lake, unpublished data; Haard, 1971). The ethylene concentration applied in this research $\left(0.5 \mu \mathrm{L} \cdot \mathrm{L}^{-1}\right)$ was well within the range of concentrations possible within a commercial storage facility. It was also likely to have had a small but quantifiable influence upon fry color.

An interaction of ethylene and $\mathrm{CO}_{2}$ could explain in part the apparently contradictory findings of various published and unpublished research into the effects of $\mathrm{CO}_{2}$ alone on potato fry color. It is possible under appropriate conditions, e.g., reduced ventilation and suf- 
ficient disease activity, that $\mathrm{CO}_{2}$ from tuber respiration and ethylene from pathogens and stressed tubers could accumulate in the potato pile to concentrations which would interact to affect fry color.

The concentration of ethylene within a potato store can be reduced by several means, such as ventilation, scrubbing with absorbents (e.g., activated charcoal) or oxidizers (e.g., potassium permanganate, ozone, $u v$ light), or hypobaric conditions to prevent accumulation to physiologically active concentrations (Kader, 1992; Knee et al., 1985; Reid, 1995; Sherman, 1985). Recent work by Prange et al. (2005) using the ethylene-action inhibitor, 1-methylcyclopropene (1-MCP), to prevent darkening of fry color resulting from ethylene sprout inhibitor leads one to hypothesize that 1-MCP may prevent the darkening described in this paper by blocking the ethylene receptors. Work is currently underway to investigate this hypothesis. $\mathrm{CO}_{2}$ concentrations in commercial potato storage buildings can be reduced by ventilation or lime scrubbers (Burton et al., 1992; Kader, 1992). However, the importance of adequate ventilation in potato storage buildings is reemphasized, since ventilation is likely the least expensive and most effective method of reducing both $\mathrm{CO}_{2}$ and ethylene concentrations in potato storage atmospheres.

\section{Literature Cited}

Arshad, M. and W.T. Frankenberger, Jr. 2002a. Ethylene in pathogenesis, p. 241-288. In: Ethylene: Agricultural sources and applications. Kluwer, New York.

Arshad, M. and W.T. Frankenberger, Jr. 2002b. Factors affecting microbial production of ethylene, p. 97-138. In: Ethylene: Agricultural sources and applications. Kluwer, New York.

Blankson, J.E. 1988. Storage carbon dioxide and the chip color of several chipping potato cultivars. MSc thesis. Univ. Guelph, Guelph, Ont., Can.

Burton, W.G., A. van Es, and K.J. Hartmans. 1992. The physics and physiology of storage, p. 608-727. In: P.M. Harris (ed.). The potato crop: The scientific basis for improvement. 2nd ed. Chapman and Hall, London, U.K.

Creech, D.L., M. Workman, and M.D. Harrison. 1973. The influence of storage factors on endogenous ethylene production by potato tubers. Amer. Potato J. 50:145-150.

Daniels-Lake, B.J., R.K. Prange, J. Nowak, S.K. Asiedu, and J.R. Walsh. 2005. Sprout development and processing quality changes in potato tubers stored under ethylene: I. Effects of ethylene concentration. Amer. J. Potato Res. (in press).

Denny, F.E. and N.C. Thornton. 1940. Factors for color in the production of potato chips. Contrib. Boyce Thompson Inst. Plant Res. 11:291-303.

Duncan, H.J. 1999. Explosion and combustion processes associated with the fogging of stored potatoes. Potato Res. 42:25-29

Duncan, H.J. and S. Kraish. 1999. Thermal fogging of potato stores with sprout suppressant formulation, p. 92-93. Proc. Euro. Assn. Potato Res. Sorrento, Italy, 2-9 May 1999.

Genstat Committee. 1993. Genstat release 3 reference manual. Clarendon Press, Oxford, U.K.

Haard, N.F. 1971. Differential response of coldstored potato tubers to ethylene. Amer. Potato J. 48:183-186.

Harkett,P. J. 1971. The effect of oxygen concentration on the sugar content of potato tubers stored at low temperature. Potato Res. 14:305-311.

Kader, A.A. 1992. Postharvest technology of horticultural crops. 2nd ed. Univ. Calif. Div. Agr. Natural Resources (Oakland) Publ. 3311.

Khanbari, O.S. and A.K. Thompson. 1994. The effect of controlled atmosphere storage at $4{ }^{\circ} \mathrm{C}$ on crisp color and on sprout growth, rotting and weight loss of potato tubers. Potato Res. 37:291-300.

Khanbari, O.S. and A.K. Thompson. 1996. Effect of controlled atmosphere and cultivar on sprouting and processing quality of stored potatoes. Potato Res. 39:523-531.

Knee, M., F.J. Proctor, and C.J. Dover. 1985. The technology of ethylene control: use and removal in post-harvest handling of horticultural commodities. Ann. Appl. Biol. 107:581-595.

Korableva, N.P. and E.P. Ladyzhenskaya. 1995. Mechanism of hormonal regulation of potato (Solanum tuberosum L.) tuber dormancy. Biochemistry 60:33-38.

Mazza, G. 1983. Correlations between quality parameters of potatoes during growth and long-term storage. Amer. Potato J. 60:145-159.

Mazza, G. and A.J. Siemens. 1990. Carbon dioxide concentration in commercial potato storages and its effect on quality of tubers for processing. Amer. Potato J. 67:121-132.

McGlasson, W.B. 1969. Ethylene production by slices of green banana fruit and potato tuber tissue during the development of induced respiration. Austral. J. Biol. Sci. 22:489-491.

Poapst, P.A., A.B. Durkee, W.A. McGugan, and F.B. Johnston. 1968. Identification of ethylene in gibberellic-acid-treated potatoes. J. Sci. Food Agr. 19:325-327.

Prange, R.K., W. Kalt, B. Daniels-Lake, C.L. Liew, R.T. Page, J.R. Walsh, P. Dean, and R. Coffin. 1998. Using ethylene as a sprout control agent in stored 'Russet Burbank' potatoes. J. Amer. Soc. Hort. Sci. 123:463-469.

Prange, R.K., B. Daniels-Lake, J.-C. Jeong, and M. Binns. 2005. Effects of ethylene and 1-methylcyclopropene on potato tuber sprout control and fry color. Amer. J. Potato Res. 82:123-128.

Rastovski,A. 1987a. Storage conditions, p. 181-182. In: A. Rastovski and A. van Es (eds.). Storage of potatoes-Post-harvest behavior, store design, storage practice, handling. Pudoc, Wageningen, the Netherlands.

Rastovski, A. 1987b. Storage losses, p.177-180. In: A. Rastovski and A. van Es (eds.). Storage of potatoes-Post-harvest behavior, store design, storage practice, handling. Pudoc, Wageningen, the Netherlands.

Reid, M.S. 1995. Ethylene in plant growth, development and senescence, p. 486-508. In: P. J. Davies (ed.). Plant hormones: Physiology, biochemistry and molecular biology. 2nd ed. Kluwer, Dordrecht, the Netherlands.

Schaper, L.A., M.T. Glynn, and J.L. Varns. 1993. Potato bin management based on respired $\mathrm{CO}_{2}$. Appl. Eng. Agr. 10:89-94.

Schouten, S.P. 1993a. Influence of temperature and carbon dioxide content on sprout growth and fry color of different potato cultivars, p. 782-788. Proc. 6th Intl. CA Res. Conf., Ithaca, N.Y.

Schouten, S.P. 1993b. Influence of low oxygen conditions during long-term (CA) storage of ware potatoes, p. 775-781. Proc. 6th Intl. CA Res. Conf., New York.

Schwobe, M.A. and K.L. Parkin. 1990. Effect of low temperature and modified atmosphere storage on sugar accumulation in potatoes (Solanum tuberosum). J. Food Process. Preserv. 14:241-252.

Sherman, M. and E.E. Ewing. 1983. Effects of temperature and low oxygen atmospheres on respiration, chip color, sugars, and malate of stored potatoes. J. Amer. Soc. Hort. Sci. 108:129-133.

Sherman, M. 1985. Control of ethylene in the postharvest environment. HortScience 20:57-60.

Smith, O. 1967. Effect of transit and storage conditions on potatoes, p. 167-217. In: W.F. Talburt and O. Smith (eds.). Potato processing. AVI, Westport, Conn.

Suttle, J.C. 2003. Auxin-induced sprout growth inhibition: Role of endogenous ethylene. Amer. J. Potato Res. 80:303-309.

Storey, R.M.J. and H.V.Davies, 1992. Tuber quality, p. 507-569. In: P.M. Harris (ed.). The potato crop: The scientific basis for improvement. 2nd ed. Chapman and Hall, London, U.K.

Viola, R. and H.V. Davies. 1992. A microplate reader assay for rapid enzymatic quantification of sugars in potato tubers. Potato Res. $35: 55-58$. 